\title{
SURVEY OF EMF EMITTED BY LAB EQUIPMENTS IN PHARMACY LABS OF SOUTHEAST UNIVERSITY IN BANGLADESH
}

\author{
Munima Haque ${ }^{1}$, Md. Quamruzzaman ${ }^{2}$ \\ ${ }^{1}$ Assistant Professor, Department of Electrical and Electronic Engineering,Southeast University, Dhaka, Bangladesh \\ ${ }^{2}$ Associate Professor, Department of Electrical and Electronic Engineering,Southeast University, Dhaka, Bangladesh
}

\begin{abstract}
The aim of this survey is to investigate whether the Electromagnetic Fields (EMF) emitted by various lab equipments affects the students. There is a standard threshold value recommended by WHO for both electric and magnetic fields. Electro-Magnetic Fields commonly known as Non Ionizing Radiation is emitted from high power transmission lines, computer monitor/video display unit, radio waves of different frequencies (extremely low frequency to microwaves), telecommunication, satellite, radar etc. which causes health hazards to living system and environment. The WHO/ International Agency for Research in Cancer (IARC) has classified radio frequency electromagnetic field as possibly carcinogenic to humans. There has been no such study performed in Bangladesh. The data were collected from various labs of department of pharmacy at Southeast University in Dhaka, Bangladesh. These labs are Pharmacentical, Cosmetology and Biopharmacentical Lab, Pharmacology Lab, Organic Pharmacy and Pharmacognosy Lab, Inorganic Pharmacy Lab and Microbiology Research Lab. Both threshold values of Electric and Magnetic fields were measured for various electronic equipments. Also the maximum value of the magnetic field results showed that in many cases the magnetic field radiated from the different sources are greater than the threshold limit which are the main point of our findings. As a result of the long time efforts of world scientist community WHO formed ICNIRP in 1969.
\end{abstract}

Key Words: EMF, NIR, DNA, EMC, AML and ICNIRP

\section{INTRODUCTION}

Radiation, which does not cause any ionization of the media while passing through it, is known a non-ionizing radiation (NIR). Examples of non-ionizing radiation are ultraviolet, visible light, infrared, microwave and radiowave. Their energy is relatively low, it only manages to cause molecules to vibrate and induces heating effects.

Exposure to Extremely Low Frequency (ELF) electric and magnetic fields does produce biological effects. However, except for fields strong enough to induce current densities above the threshold for the stimulation of nerve tissue, there is no consensus as to whether these effects constitute a hazard to human health. Fields at radio frequencies from $300 \mathrm{kHz}$ to $300 \mathrm{GHz}$ are quantified in terms of electric field strength $(\mathrm{V} / \mathrm{m})$ and magnetic field strength $(\mathrm{A} / \mathrm{m})$. At frequencies above $300 \mathrm{MHz}$, power density $\left(\mathrm{W} / \mathrm{m}^{2}\right)$ is usually used in hazard evaluation. Except for field far from sources, both the electric and the magnetic fields may have to measure for complete specification. Contact with large, ungrounded metal objects in the presence of strong RF fields may be hazardous. There is very little information on the effects of RF radiation on man and limited data on responses of animal exposed to frequencies above $10 \mathrm{GHz}$ and below $10 \mathrm{MHz}$; most animal research has been carried out at frequencies near $3 \mathrm{GHz}$. Since magnetic field is more harmful than electric field, there must be a limit both in the residential and occupational levels between 0.2 to $0.3 \mu \mathrm{T}$ or $2.5 \mathrm{mG}$. (This value is internationally recognized as standard limit in many countries). Also, for electric field this value is $25 \mathrm{~V} / \mathrm{m}$.
Nancy Wertheimer was the first scientist responsible for identifying the association between magnetic fields and childhood leukemia [1]. It is reported that high power transmission lines [2][3], computer monitor/video display unit, radio waves of different frequencies in (extremely low frequency to microwaves) telecommunication, satellite, radar etc. also cause harm to living systems [4][5], especially in human beings for example. It is known that high power transmission lines cause human health hazards rather than a common electrocution. There are also evidences that the cause of clinical depression and commitment of suicide are related with the emission from the power lines [6][7]. A significant percentage of miscarriage is recorded among women using electric blankets, electrically heated waterbeds and video display unit or computer monitor. There are instances that occupational hazards like risk of developing Acute Myeloid Leukemia (AML) may occur among the people working in the field of telecommunication. Cancerous thyroid tumor, suppression of T- lymphocyte cell etc. are also found to occur among the persons exposed to non-ionizing radiation. Lower animals are reported to very much sensitive to electromagnetic fields. It is observed that animals like rats make their living brooding holes away from the high electric field and bees block-up their hives in the chronic presence of NIR/EMF.

As a consequence, scientists and health physicians in developed countries have become aware of the effects of NIR [8]. Their research and observations have brought out some remarkable results linking low level alternating electromagnetic fields with serious health hazards. The 50 
$\mathrm{Hz}$ and $60 \mathrm{~Hz}$ power lines fields (low frequency), pulsed radar systems and high power Extremely High Frequency (EHF) communication systems are genuine concerns for mankind. It is suspected that the cause of Sudden Infant Death Syndrome (SIDS) may have some relation with EMF. There is also evidence that biological effect like immune deficiency, sensitive ly mphocytes, disrupting DNA, cellu lar breakdown is being affected by NIR.

EMFs might affect the production of agents like free radicals, which themselves can react with DNA or other agents that cause chromosomal damage, instigating translocation by inducing DNA breaks or by formation of unnatural DNA structures. Fields $(0.2 \mathrm{mT})$ at $60 \mathrm{~Hz}$ have been reported to be comutagenic in Salmonella, causing a $14 \%$ increase in azide-induced mutations after $48 \mathrm{~h}$ exposure [9]. Hu man ly mphocytes exposed to sinusoidal 50 $\mathrm{Hz}, 60 \mathrm{~Hz}$, or pulsed EMFs did not undergo detectable chromosomal alterations or inhibition of DNA repair mechanis ms [10][11][12][13] [14] [15] [16]. Primary human lymphocytes have been reported to show increased micronuclei formation when exposed to 75 or $150 \mu \mathrm{T}$ fields at $32 \mathrm{~Hz}$, but only when a parallel $42 \mu \mathrm{T}$ d.c. field was applied concurrently to establish the cyclotron and paramagnetic resonance condition for calcium [17], it increases in chromosome defects (gap and break frequencies) in human amniotic cells exposed to a continuous or intermittent $30 \mu \mathrm{T}$ sinusoidal field at 50 $\mathrm{Hz}[18]$.

Much research has been performed in this regard. Most recently, Epidemiological survey of people working in EMF field exposed to high frequency have been investigated [19]. Also, research was performed for epidemiological survey on effect of EMF emitted by photocopy machines generally used in Dhaka city Bangladesh [20]. Survey was done on EMF emitted by Lab equipments in various labs of Southeast University in Bangladesh for possible health hazards [21]. A case study was done on EMF near high voltage transmission line [22]. Also, a review was done on Non Ionizing Radiation (NIR), its harmful effects especially from Mobile/Cell Phone and Towers [23]

There have been various papers published on EMF of radio, TV etc. but not much on lab equipments. The students will be the professional people in future and they are involved with lab equipments. The aim of this effort is to save the professionals who will be working with various lab equipments and will be exposed to NIR for longer period.

\subsection{Methods}

A magnetic Science International MF meter (Serial No 624335: Range 1 mGauss -700 Gauss) was used for measuring the magnetic field values for the various lab equipments. A Cughill Field Mouse for Biohazard Awareness was used for measuring the threshold values for both electric field and magnetic field around the instrument. This instrument was designed by Dr. Roger Coghill of UK. The students filled the measurement table for measuring the equipments. The readings were taken to cover all around the equipment.

\subsection{RESULTS}

Findings at different EMF sources: All the readings were taken from different labs of Pharmacy department, Southeast University Banani campus.

In Tables 1 and 2, experimental data were collected from the Pharmaceutical, Cosmetology and Biopharmaceutical Lab and Pharmacology Lab respectively. Mixer machine, Friability test apparatus, Dissolution test apparatus, Ultrasonic cleaner and magnetic stirrer hotplate were used for these measurements for Pharmaceutical, Cosmetology and Biopharmaceutical Lab. Rotary evaporator and Centrifuge machine were used for these measurements for the Pharmacology Lab. Electric field and magnetic field threshold distance located at the front, back and at $45^{\circ}$ angle both right and left side has been measured for the equipments. Also, the magnetic field values at these locations were measured. The maximum magnetic field values were measured for each equipment of these labs.

In tables 3 and 4, experimental data were collected from the Organic Pharmacy and Pharmacognosy Lab \& Inorganic Pharmacy Lab and Microbiology Research Lab respectively. Drier, Water bath, and oven were used for these measurements for the Organic Pharmacy and Pharmacognosy Lab \& Inorganic Pharmacy Lab. Laminar flow cabinet, Autoclave and Binder were used for these measurements for Microbiology Research Lab. Electric field and magnetic field threshold distance located at the front, back and at $45^{\circ}$ angle both right and left side has been measured for the equipments. Also, the magnetic field values at these locations were measured. The maximum magnetic field values were measured for each equipment of these labs.

In table-1 Pharmaceutical, Cosmetology and Biopharmaceutical Lab, no 1 equipment the mixer machine was motor type. So, electric field may be zero. The no. 2 equipment Friability test apparatus is old. So, the magnetic field is so high. Same with no. 3 equipment the Dis solution test apparatus digital. It is old and so the magnetic field is up to hundred.

In table-2 Pharmacology Lab, no.1 equipment the Rotary evaporator is new. So, electric and magnetic field are medium. For the centrifugal machine, the magnetic field is too high to be measured by the machine. So, it was over 200 $\mathrm{mG}$.

In table-3 Organic Pharmacy and Pharmacognosy Lab \& Inorganic Pharmacy Lab, equipment no. 1 the drier was very old. Therefore, the magnetic field was above $200 \mathrm{mG}$. For the water bath, the magnetic field in this case has been influenced by an electric switch from nearby wall. The oven was comparatively new. So, the magnetic field threshold value was 0 (zero).

In table-4 Microbiology Research Lab, both the laminar flow cabinet and the autoclave equipment are new. So, in both cases, the electric fields are 0 (zero) and the magnetic 
field is low. On the other hand, the Binder equipment was old, both the electric field and magnetic field threshold values are high and the magnetic field maximum was above $200 \mathrm{mG}$.

Table 1: EMF measured from lab equipments location address: Pharmaceutical, Cosmetology and Biopharmaceutical Lab

\begin{tabular}{|c|c|c|c|c|c|c|c|c|}
\hline \multirow[t]{2}{*}{$\begin{array}{l}\text { Serial } \\
\text { No. }\end{array}$} & \multirow[t]{2}{*}{$\begin{array}{l}\text { Equipment info. } \\
\text { (Machine \#, Machine } \\
\text { Model, } \\
\text { Date of installation) }\end{array}$} & \multicolumn{2}{|c|}{$\begin{array}{l}\text { Threshold dis. in front } \\
\text { of the screen measured } \\
\text { from the centre of the } \\
\text { equipment }(\mathrm{cm})\end{array}$} & \multicolumn{2}{|c|}{$\begin{array}{l}\text { Threshold dis. at } 45^{\circ} \\
\text { angle from the normal } \\
\text { drawing at the centre } \\
(\mathrm{cm})\end{array}$} & \multicolumn{2}{|c|}{$\begin{array}{l}\text { Threshold } \\
\text { distance at the } \\
\text { top of the } \\
\text { equipment }(\mathrm{cm})\end{array}$} & \multirow[t]{2}{*}{$\begin{array}{l}\text { Magnetic } \\
\text { Field } \\
\text { maximum } \\
(\mathrm{mG})\end{array}$} \\
\hline & & $\mathrm{EF}$ & $\mathrm{MF}$ & $\mathrm{EF}$ & MF & $\mathrm{EF}$ & $\mathrm{MF}$ & \\
\hline 1 & $\begin{array}{l}\text { Mixer Machine Model } \\
\text { name: Remi motor. Orig in- } \\
\text { India }\end{array}$ & 0 & 24 & 0 & 33 & 0 & 6 & $>200$ \\
\hline 2 & $\begin{array}{l}\text { Friability test } \\
\text { Model name: } \\
\text { Origin-India }\end{array}$ & 41 & 52 & 48 & 49 & 43 & 44 & $>200$ \\
\hline 3 & $\begin{array}{l}\text { Dissolution test Apparatus } \\
\text { Digital Model name: } \\
\text { Toshiba Origin-India }\end{array}$ & 16 & 18 & 13 & 63 & 67 & 68 & 110 \\
\hline 4 & $\begin{array}{l}\text { Ultrasonic cleaner Model } \\
\text { \#Ud200 SH-6L Orig in- } \\
\text { Takashi Japan }\end{array}$ & 0 & 7 & 0 & 14 & 0 & 82 & 8 \\
\hline 5 & $\begin{array}{l}\text { Magnetic stirrer hot plate } \\
\text { Model\#78-1 Origin-China }\end{array}$ & 6 & 32 & 25 & 20 & 0 & 34 & 54 \\
\hline
\end{tabular}

Table 2: EMF measured from lab equip ments location address: Pharmacology Lab

\begin{tabular}{|c|c|c|c|c|c|c|c|c|}
\hline \multirow[t]{2}{*}{$\begin{array}{l}\text { Serial } \\
\text { No. }\end{array}$} & \multirow[t]{2}{*}{$\begin{array}{l}\text { Equipment info. } \\
\text { (Machine \#, Machine } \\
\text { Model, } \\
\text { Date of installation) }\end{array}$} & \multicolumn{2}{|c|}{$\begin{array}{l}\text { Threshold dis. in front of } \\
\text { the screen measured from } \\
\text { the centre of the equipment } \\
(\mathrm{cm})\end{array}$} & \multicolumn{2}{|c|}{$\begin{array}{l}\text { Threshold dis. at } 45^{\circ} \\
\text { angle from the normal } \\
\text { drawing at the centre } \\
(\mathrm{cm})\end{array}$} & \multicolumn{2}{|c|}{$\begin{array}{l}\text { Threshold distance } \\
\text { at the top of the } \\
\text { equipment }(\mathrm{cm})\end{array}$} & \multirow[t]{2}{*}{$\begin{array}{l}\text { Magnetic } \\
\text { Field } \\
\text { maximum } \\
(\mathrm{mG})\end{array}$} \\
\hline & & $\mathrm{EF}$ & MF & $\mathrm{EF}$ & $\mathrm{MF}$ & $\mathrm{EF}$ & $\mathrm{MF}$ & \\
\hline 1 & $\begin{array}{l}\text { Rotary evaporator } \\
\text { Model-RE3022-C } \\
\text { Origin-UK }\end{array}$ & 0 & 38 & 43 & 62 & 3 & 25 & 45 \\
\hline 2 & $\begin{array}{l}\text { Centrifuge Machine } \\
\text { Model\#DSC-100A-2 } \\
\text { Origin-Taiwan }\end{array}$ & 15 & 51 & 25 & 36 & 35 & 41 & $>200$ \\
\hline
\end{tabular}

Table 3: EMF measured from various lab equipments location address: Organic Pharmacy and Pharmacognosy Lab \& Inorganic Pharmacy Lab

\begin{tabular}{|c|c|c|c|c|c|c|c|c|}
\hline \multirow[t]{2}{*}{$\begin{array}{l}\text { Serial } \\
\text { No. }\end{array}$} & \multirow[t]{2}{*}{$\begin{array}{l}\text { Equipment info. } \\
\text { (Machine \#, Machine } \\
\text { Model, } \\
\text { Date of installation) }\end{array}$} & \multicolumn{2}{|c|}{$\begin{array}{l}\text { Threshold dis. in front of } \\
\text { the screen measured from } \\
\text { the centre of the } \\
\text { equipment }(\mathrm{cm})\end{array}$} & \multicolumn{2}{|c|}{$\begin{array}{l}\text { Threshold dis. at } 45^{\circ} \\
\text { angle from the normal } \\
\text { drawing at the centre } \\
(\mathrm{cm})\end{array}$} & \multicolumn{2}{|c|}{$\begin{array}{l}\text { Threshold distance } \\
\text { at the top of the } \\
\text { equipment }(\mathrm{cm})\end{array}$} & \multirow[t]{2}{*}{$\begin{array}{l}\text { Magnetic } \\
\text { Field } \\
\text { maximum } \\
(\mathrm{mG})\end{array}$} \\
\hline & & $(\mathrm{EF})$ & MF) & $\mathrm{EF}$ & MF & $\mathrm{EF}$ & MF & \\
\hline 1 & $\begin{array}{l}\text { Drier Model\#Y51112075 } \\
\text { Origin-Huanghua YOM- } \\
\text { Nov/05 }\end{array}$ & 24 & 100 & 55 & 103 & 65 & $>200$ & $>200$ \\
\hline 2 & $\begin{array}{l}\text { Water bath Model\#HH-S } \\
\text { Origin-China Jiangsu }\end{array}$ & 27 & 6 & 24 & 6 & 23 & 61 & $>200$ \\
\hline 3 & $\begin{array}{l}\text { Oven Model\#DSO500D } \\
\text { Origin-Taiwan }\end{array}$ & 3 & 0 & 2.5 & 0 & 1.5 & 0 & 22 \\
\hline
\end{tabular}


Table 4: EMF measured from lab equipments location address: Microbiology Research Lab

\begin{tabular}{|c|c|c|c|c|c|c|c|c|}
\hline \multirow[t]{2}{*}{ Serial No. } & \multirow[t]{2}{*}{$\begin{array}{l}\text { Equipment info. } \\
\text { (Machine \#, Machine Model, } \\
\text { Date of installation) }\end{array}$} & \multicolumn{2}{|c|}{$\begin{array}{l}\text { Threshold dis. in } \\
\text { front of the screen } \\
\text { measured from } \\
\text { the centre of the } \\
\text { equipment }(\mathrm{cm})\end{array}$} & \multicolumn{2}{|c|}{$\begin{array}{l}\text { Threshold dis. at } \\
45^{\circ} \text { angle from the } \\
\text { normal drawing at } \\
\text { the centre }(\mathrm{cm})\end{array}$} & \multicolumn{2}{|c|}{$\begin{array}{l}\text { Threshold } \\
\text { distance at the } \\
\text { top of the } \\
\text { equipment }(\mathrm{cm})\end{array}$} & \multirow[t]{2}{*}{$\begin{array}{l}\text { Magnetic } \\
\text { Field } \\
\text { maximum } \\
(\mathrm{mG})\end{array}$} \\
\hline & & $\mathrm{EF}$ & $\mathrm{MF}$ & $\mathrm{EF}$ & MF & $\mathrm{EF}$ & MF & \\
\hline 1 & $\begin{array}{lll}\text { Laminar flow } & \text { cabinet } \\
\text { Model\#IEC-61010-1, } & \text { Origin- } \\
\text { Singapore } & \\
\end{array}$ & 0 & 9 & 0 & 34 & 0 & 23 & 3.5 \\
\hline 2 & $\begin{array}{l}\text { Autoclave Model\#RAU-530 } \\
\text { Origin-Taiwan } \\
\text { Aug/2009 Dec/2010 }\end{array}$ & 0 & 53 & 0 & 15 & 0 & 20 & 18.9 \\
\hline 3 & $\begin{array}{lcc}\text { Binder } & \text { Model\#BD53 } & \text { Si\#09- } \\
\text { 05266 Origin-Germany } & \text { YOM- } \\
2005 \text { Dec/2010 } & \end{array}$ & 26 & 81 & 22 & 59 & 34 & 49 & $>200$ \\
\hline
\end{tabular}

\section{DISCUSSIONS}

It was found from the results that the magnetic field values are much higher than the threshold level. Because of the nature of the wiring both in the ceiling and floor, most of the rooms had higher magnetic field than threshold value. Students work on an average of 3-6 hours a day in those labs. We have in mind to include other labs for the study to continue.

A potential hazard to health can be produced either as a result of the exposure of the human body to NIR, or by interaction with technical devices, which are themselves affected by NIR and they give rise to health hazards (e.g. interference with electro medical devices, unintentional triggering of electrically activated detonator and ignition of flammable materials). This is especially true if the individuals concerned are not aware of the potential hazard to be unable to identify it.

\section{CONCLUSIONS}

From the above lab results, it has been found that in most cases the magnetic field has crossed threshold value. The electric field also has a higher threshold value in some of the equipments. Also, the magnetic field maximum exposure was over $200 \mathrm{mG}$ in many cases. Wiring must be done according to the building code 2012.It is hoped that this survey will be helpful as a preventive measure for students who might get affected tomo rrow.

\section{REFERENCES}

[1]. N Wertheimer, ED Leeper, 1979: Electrical wiring configurations and childhood cancer. American journal of Epidemiology. Oxford Univ Press (1979)

[2]. M. Coleman; V. Bera., 1988: A Review of Epidemiological Studies of the Health Effects of Living Near or Working with Electricity Generation and Transmission Equipment. International Journal of Epidemiology. 17 (1): 1-13

[3]. G. Draper; T. Vincent; M.E. Kroll; J. Swanson., 2005: Childhood cancer in relation to distance from high voltage power lines in England and Wales: a casecontrol study. BMJ. 330 (7503): 1290
[4]. J.M. Al-Bareeq., 1998: Health Risks of Electromagnetic Field. Editorial. Bahrain Medical Bulletin. 20(1)

[5]. Z. Ziang. Considering factors in Chinese EMF standard. 3rd International EMF Seminar in China: Electromagnetic Fields and Biological Effects. Guilin, China: October 13-17, 2003. [Retrieved on 05.08.2012]

[6]. [http://www.who.int/pehemf/meetings/archive/en/proceedings_eng.pdf\#page $=8$ 9] (2003)

[7]. E. van Wijngaarden; D. A. Savitz; R.C. Kleckner; J. Cai; D. Loomis, 2000: Exposure to electromagnetic fields and suicide among electric utility workers a nested case-control study. West J Med. 173(2): 94-100 (2000)

[8]. K. J. Fernie; S. J. Reynolds., 2005: The Effects of Electromagnetic Fields from Power Lines on Avian Reproductive Biology and Physiology: a Review. Journal of Toxicology and Environmental Health, Part $B, 8: 127-140$

[9]. Repacholi, M. H., 2003: An Overview of WHO's EMF Project and the Health Effects of EMF Exposure. Proceedings of the International Conference on NonIonizing Radiation at UNITEN (ICNIR 2003), Electromagnetic Fields and Our Health.

[10]. Tabrah, F. L., Mower, H. F., Batkin, S., and Greenwood, P. B. 1994 Enhanced mutgenic effect of a $60 \mathrm{~Hz}$ time-varying magnetic field on numbers of azide-induced TA100 revertant colonies. Bioelectromagnetics 15, 85-93

[11]. Nafziger, J., Desjobert, H., Benamar, B., Guillosson, J. J., and Adolphe, M., 1993: DNA mutations and $50 \mathrm{~Hz}$ electromagnetic fields. Bioelectrochem. Bioenerg. 30, 133-141

[12]. Cadossi, R., Bersani, F., Cossarizza, A., Zucchini, P., Emilia, G., Torelli, G., and Francheschi, C., 1992: Lymphocytes and low-frequency electromagnetic fields. FASEB J. 6, 2667-2674

[13]. Cohen, M. M., Kunska, A., Astemborski, J. A., McCulloch, D., and Pasekewitz, D. A., 1986: Effect of low-level $60 \mathrm{~Hz}$ electromagnetic fields on human lymphoid cells: I. Mitotic rate and chromosome 
breakage in human peripheral lymphocytes. Bioelectromagnetics 7, 415-423

[14]. Cohen, M. M., Kunska, A., Astemborski, J. A., McCulloch, D., and Pasekewitz, D. A., 1986: Effect of low-level $60 \mathrm{~Hz}$ electromagnetic fields on human lymphoid cells: II. Sister chromatid exchanges in peripheral lymphocytes and lymphoblastoid cell lines. Mutat. Res. 172, 177-184

[15]. Frazier, M. E., Samuel, J. E., and Kaune, W. T., 1984: Viabilities and mutation frequencies of $\mathrm{CHO}-\mathrm{K} 1$ cells following exposure to $60-\mathrm{Hz}$ electric fields. 232nd Hanford Life Sciences Symposium, pp. 255-267, Richland, Oregon

[16].Livingstone, G. K., Gandi, O. P., Chatterjee, I., Witt, K., and Roti Roti, J. L., 1986: Reproductive integrity of mammalian cells exposed to $60 \mathrm{~Hz}$ electromagnetic fields. (Report submitted to New York State power lines project)

[17]. Rosenthal, M., and Obe, G. 1989: Effect of $50 \mathrm{~Hz}$ electromagnetic fields on proliferation and on chromosomal alterations in human peripheral lymphocytes untreated or pre-treated with chemical mutagens. Mutat. Res. 210, 329-335

[18]. Tofani, S., Ferrara, A., Anglesio, L., and Gilli, G. 1995: Evidence for genotoxic effects of resonant ELF magnetic fields. Bioelectrochem. Bioenerg. 36, 9-13

[19]. Nordenson, I., Mild, K. H., Andersson, G., and Sandström, M., 1994: Chromosomal aberrations in human amniotic cells after intermittent exposure to fifty hertz magnetic fields. Bioelectromagnetics 15 , 293-301

[20]. M. Quamruzzaman, and M. Haque. 2012: Epidemiological Survey of People Working in EMF Field Exposed to High Frequency. Proceedings of the Global Engineering, Science and Technology Conference 2012, 28-29 December, Dhaka, Bangladesh

[21]. M. Haque and Md. Quamruzzaman 2015: Epidemiological survey on effect of EMF emitted by photocopy machines generally used in Dhaka city Bangladesh. IJRET: International Journal of Research in Engineering and Technology. Volume 4, Issue 4, April 2015, pp 92-100

[22]. M. Quamruzzaman, M.Haque, 2015: Survey of EMF emitted by Lab equip ments in various labs of Southeast University in Bangladesh for possible preventive health hazards. IFRSA International Journal Of Electronics Circuits And Systems. Pp 26-32, Volu me 4, is sue 1, Jan 2015, pp 26-32

[23]. M. Quamruzzaman, Munima Haque, Farruk Ahmed, Md. Shahab Zaman, 2014: Effects of electromagnetic fields (EMF) near high voltage transmission line: a case study. Bangladesh Journal of Medical Physics Volume 7, Issue 1

[24]. M. Quamruzzaman, M. Haque, 2014: Non Ionizing Radiation (NIR), its harmful effects especially from Mobile/Cell Phone and Towers. Southeast University Journal of Science and Engineering, Volu me 8, Is sue 1 